\title{
Notes on Urban Wildlife in the City of Managua, Nicaragua
}

\section{Antonio Mijail Pérez}

As a result of some spot observations conducted on Managua, capital city of Nicaragua, a preliminary list of mollusks and birds was published. The list was made up of 18 species, 12 families and three orders of mollusks as well as 41 species, 23 families and 9 orders of birds. These values are consistent with total species numbers estimated by experts on these taxa for the country. This was the first inventory from these taxa associated to the city of Managua, where previous data on trees already existed. These results are analyzed in the light of existing literature on the subject.

Keywords: Mollusks / Birds / Managua city / Urban Ecology

Urban spaces are structures heterogeneous in size, shape and nature, a quality which may facilitate the survival of some species in an urban habitat. They include patches of forests, urban parks and peripherals, linear features (river banks and edges of streets), spot elements (isolated trees), small green areas (public and private gardens), and other spaces with low intensity use (cemeteries and vacant lots). The area and composition of green spaces in cities are greatly variable in the world and depend on prior characteristics of each settlement, the historical pattern of urbanization, and development policies (Rebele, 1994; Dana, Vivas \& Mota, 2002).

Webb and Foster (1990) compiled several articles that address different aspects of urban ecology, and general aspects of the urban ecosystem, wildlife in cities, and improving habitat for these species. Twenty years after this publication, the analysis and the problems remain essentially the same. Other initiatives presented efforts to achieve connectivity between natural areas within the urban environments of the cities of Barcelona (Marull \& Mallarach, 2002) and Madrid (Sastre, De Lucio $\&$ Martínez, 2002). Likewise, the city of San Jose, Costa Rica, is already beginning to 
take actions to consider riverbeds as biodiversity reservoirs and connectors between patches of natural areas (various authors, personal communication).

Studies of the biota associated with urban areas in Nicaragua are scarce. According to our data we only have the study by Salas (1984) on trees in Managua, where 531 species were cited for the city, as well as a recent article on lizards (Ctenosaura similis) in the courtyards of the city of León (González-García, Belliure, Gómez-Sal \& Dávila, 2009).

The city of Managua is the capital of the Republic of Nicaragua. It has a population density of 1,817,096 inhabitants (2004) in the metropolitan area. The city limits to the North with Lake Managua, to the South with San Marcos and San Rafael del Sur, to the East with Tipitapa, Nindirí, and Ticuantepe, and to the West with Villa Carlos Fonseca, Mateare. It has a surface of $544 \mathrm{~km}^{2}$ and an altitude of 82.97 meters. Its coordinates are $12^{\circ} 9^{\prime} \mathrm{N} \mid 8^{\circ} 16^{\prime} \mathrm{W}$. Managua is characterized by a particularly hot and humid climate, mainly tropical, with temperatures from $27^{\circ}$ to $38^{\circ}$ Celsius. The rainy months are between May and December, and during the rest of the year it is difficult to see a single raindrop in any part of the city (Alcaldía de Managua, 2010).

According to preliminary data from Pérez and Zolotoff (2010), the molluscan fauna of the city of Managua is composed of 18 species, 12 families and 3 orders of molluscs and 41 species, 23 families and 9 orders of birds. These results are consistent with the estimated numbers of species for these groups in the country by Pérez, López, Urcuyo \& Sotelo (2003) in the case of mollusks, with an estimated 260 mainland species, and Martínez-Sánchez (2007) with 706 species of birds estimated. Whereas the data presented are observations related to a few isolated parts of the city, one can conclude that the species richness observed in these groups in the city is relatively high.

In the case of mollusks, data of species richness in communities associated with silvopastoral systems in Central America range between 8 and 18 (Perez et al., 2005), and on silvopastoral systems in Nicaragua from 13 to 35 species (Perez et al., 2006). The bird data were obtained for species richness in communities associated with silvopastoral systems of Central America hovering around 17 species (Pérez et al., 2005) and between 22 and 68, in silvopastoral systems in Nicaragua (Pérez et al., 2006).

According to Pysek (1998) and McKinney (2002), it has been extensively tested that urban areas are richer in species than their surroundings for a variety of taxonomic groups. According to the first author, as urban areas represent refuges for many threatened native species, specific knowledge about the causes of species richness in cities and the processes that lead to the homogenization of urban floras are crucial for the effective protection of urban biodiversity.

Despite the significant destruction and degradation of habitats, urban areas have the ability to sustain a wide diversity of animal species of vertebrates and invertebrates, perhaps because of the diverse range of natural and artificial habitats and conditions that occur in urban areas (Niemelä, 1999a, b; Collins, Kinzing \& Grimm, 2000). Kühn, Brandl \& Klotz (2004), however, argue that the high species diversity in urban areas takes place not because but in spite of urbanization, with urban development often coinciding with areas of high species diversity and 
endemism, such as coastal and tropical regions.

In this sense there are others authors who believe that the impact of human activities on ecological systems is well illustrated by changes in land use resulting from urbanization, the consequences are a serious threat to biodiversity conservation across the world (McKinney, 2002), and could lead to the eradication of a large number of species in the affected habitats (Marzluff, Bowman \& Donelly, 2001; Chace \& Walsh, 2006), especially in developing countries located in tropical latitudes (Marzluff, 2001), like ours.

\section{References}

Alcaldía de Managua. (2010). Managua. Available from: www.managua.gob.ni

Chace, J. F. \& Walsh, J.J. (2006). Urban effects on native avifauna: a review. Landscape and Urban Planning, (74), 46-69.

Collins J. P., Kinzing, A. \& Grimm, N. B. (2000). A new urban ecology. Am. Sci., (88), 416-24.

Dana, E. D., Vivas, S., \& Mota, J. F. (2002). Urban vegetation of Almería City- a contribution to urban ecology in Spain. Landsc. Urban Plan, (59), 203-216. doi:10.1016/S0169-2046(02)00039-7.

González-García, A. J., Belliure, A., Gómez-Sal, A. \& Dávila, P. (2009). The role of urban greenspaces in fauna conservation: the case of the iguana Ctenosaura similis in the 'patios' of León city, Nicaragua. Biodivers. Conserv., (18), 19091920. DOI 10.1007/s10531-008-9564-4

Kühn, I., Brandl, R. \& Klotz, S. (2004). The flora of German cities is naturally species rich. Evol. Ecol. Res., (6), 749-64.

McKinney, M. L. (2002). Influence of settlement time, human population, park shape and age, visitation and roads on the number of alien plant species in protected areas in the USA. Diversity and Distributions,(8), 311-318.

Martínez-Sánchez, J. C. (2007). Lista patrón de las aves de Nicaragua. Managua: ALAS. Marull, J. \& Mallarach, J. M. (2002). La conectividad ecológica en el Área Metropolitana de Barcelona. Ecosistemas, (2), Available from: www.aeet.org/ ecosistemas/022/investigacion6.htm.

Marzluff, J.M., Bowman, R. \& Donelly, R. (2001). A historical perspective on urban bird research: trends, terms, and approaches. In J. M. Marzluff, R. Bowman \& R. Donelly, (Eds.). Avian Ecology and Conservation in an Urbanizing World. (pp.1-17). Norwell: Kluwer Academic Press.

Niemelä, J. (1999a). Ecology and urban planning. Biodivers. Conserv., (8),119-31.

Niemelä, J. (1999b). Is there a need for a theory of urban ecology?. Urban Ecosyst., (3), 57-65.

Pérez, A. M., López, A., Urcuyo, J. \& Sotelo, M. (2003). Sinopsis cuantitativa de la malacofauna de Nicaragua. Malacologia Latinoamerica, 401-404.

Pérez, A. M. \& Zolotoff, J. M. (2010). Datos preliminares sobre moluscos y aves de la ciudad de Managua, Nicaragua. Gaia, (12),1-33.

Pérez, A. M., Bornemann, G., Campo, L., Sotelo, M., Ramírez, F. \& Arana, I. (2005). Relaciones entrebiodiversidady producción en sistemassilvopastorilesdeAmérica 
Central. Ecosistemas, 14(2) Available from: http://www. revistaecosistemas.net /articulo.asp? Id=113\&Id_Categoria=2\& tipo=portada.

Pérez, A. M., Sotelo, M., Ramírez, F., Ramírez, I., López, A. \& Siria, I. (2006). Conservación de la biodiversidad en sistemas silvopastoriles de Matiguás y Rio Blanco, Dpto de Matagalpa, Nicaragua. Ecosistemas, 15, (3), 125-141).

Pysek, P. (1998). Alien and native species in central European urban floras: A quantitative comparison. Journal of Biogeography 25, 155-163.

Rebele, F. (1994). Urban ecology and special features of urban ecosystems. Glob. Ecol. Biogeography Lett., (4),173-187. doi:10.2307/2997649.

Salas, J. B. (1984). Flora arborescente de la ciudad de Managua y sus alrededores. Managua: IRENA.

Sastre, P., De Lucio, J. V. \& Martínez, C. (2002). Modelos de conectividad del paisaje a distintas escalas. Ejemplos de aplicación en la Comunidad de Madrid. Ecosistemas, (2) Available from: www.aeet.org/ecosistemas/022/ investigacion 5.htm.

Stiles, F.G. \& Skutch, A. (1998). Guia de Aves de Costa Rica. (2a ed.).Heredia, Costa Rica: INBIO.

Webb, E.A. \& Foster, S. Q. (1990). Perspectives in urban ecology. Colorado: Denver Museum of Natural History and Thorne Ecological Museum. 